\title{
Cytokine flames of COVID-19
}

\begin{abstract}
Ahmed Imran Siddiqi ${ }^{1,2}$
${ }^{1}$ Department of Medicine, Jersey General Hospital. The Parade, St Helier, JE1 3QS, Channel Island Jersey, UK Island Jersey, UK. DOI:10.31579/2692-9392/014

COVID-19 (Corona Virus Disease 2019) is leaving clinicians and scientists baffled with its clinical presentation spectrum ranging from completely asymptomatic patients with complete and smooth recovery to fatal outcomes in apparently healthy, young and immunocompetent individuals within days even with the support of most advanced healthcare staff and logistic facilities. This inability of clinicians to offer a convincing approach to meet this daunting worldwide healthcare challenge that the world has not seen at least in a hundred years has left the general public with no choice except to agree with WHO recommendation of shunning their daily lives and lock themselves up indoors to avoid contracting and spreading this condition despite estimated mortality of approximately $2 \%$ [1]. This global healthcare challenge has spiraled out of control with implications already on the international economic climate, employment figures even in most developed parts of the world and almost all other aspects of life. With all this in the background, clinicians, and scientists worldwide have so far come up with two main words - Cytokine storm and Dexamethasone.
\end{abstract}

${ }^{2}$ Shaukat Khanam Memorial Cancer Hospital and Research Center 7-A R-3 Johar Town Lahore.

Corresponding author: Ahmed Imran Siddiqi, Department of Medicine, Jersey General Hospital. The Parade, St Helier, JE1 3QS, Channel

Received date: June 24, 2020; Accepted date: July 16, 2020; Published date: July 25, 2020

Citation: Ahmed I. Siddiqi., (2020) Cytokine flames of COVID-19. J. Archives of Medical Case Reports and Case Study. 3(1);

Copyright: (C) 2020 Ahmed Imran Siddiqi, This is an open access article distributed under the Creative Commons Attribution License, which permits unrestricted use, distribution, and reproduction in any medium, provided the original work is properly cited.
"Cytokine storm" is believed to be the prognosis defining event in the disease journey of COVID-19 patients. COVID-19 patients mostly take 5 to 7 days to develop features of this critical pathological sequence of irreversible events associated with a rapid and significant decline in the clinical condition of patients and fatal outcomes. This condition is not unique to COVID-19 infection and, in my knowledge was first used in literature in 1993 for patients suffering from graft versus host disease [2]. Over the previous twenty-seven years, many pathological conditions have triggered this specific sequence of events - viruses, bacteria, graft versus host disease, multiple sclerosis, pancreatitis, and H5N1 infection. [3] Since these different triggers end up in the activation of this specific sequence of events it seems reasonable to assume that all these triggers converge at one single point that switches on "Cytokine storm". This single point is believed to be our immune system comprising of groups of specialized cells of innate (non-specific but immediate response part of the immune system) and antigen-specific ( $\mathrm{T}$ cells and $\mathrm{B}$ cells mediated highly antigen-specific part of the immune system). In a nutshell, in addition to many other specific and highly specialized functions these cells of our immune system release certain chemicals mostly for functions at the local tissue level to fight the pathogenic organism or any other trigger. This ends up in killing the offending organism but some of our own cells die in this process as well. This immune system response is normal and physiological to fight infections at the tissue level in our body. If this response is exaggerated by several folds the destruction at tissue level can be catastrophic, impairing the functioning of that tissue. Oxygenation would be critically impaired if the lungs are the affected tissues like in H5N1 infected patients with acute lung injury and now COVID-19 infected patients [3]. I think we stand here struggling to draw the line to differentiate between the physiological level of immune system response essential to fight off the offending agent and level of immune system response considered pathological culminating in a Cytokine storm and fatal outcomes in COVID-19 patients. The Rapid rise in D-dimer level, ferritin levels [4]. and increased requirement of supplemental Oxygen levels are being used in COVID-19 infected patients to identify patients with poor outcomes. It is still to be seen the success rate of these investigations in achieving this goal. Having said that, the more important question for me still remains unanswered "why do some, and not all patients end up developing this cytokine storm"?

I feel it is essential for us clinicians to be able to identify these potential candidates of developing cytokine storm to use steroids early enough to avoid a full-blown, irreversible, clinically catastrophic and fatal cytokine storm.

The ubiquitous presence of glucocorticoid (GC) receptors on immune system cells allow GC to have a significant influence on the functioning of these cells. The final response does not only depend on the type of immune cell but also at the stage of differentiation of that immune cell. Successful steroids' use in the treatment of other conditions associated with cytokine storm made them the most likely candidates of all to affect the progression of this natural but exaggerated inflammatory response to a pathological range in COVID-19 patients. Graft versus host disease, autoimmune conditions like rheumatoid arthritis, inflammatory bowel disease, and other similar conditions require steroid use during the acute phase of these conditions. Glucocorticoids dampen down the immune response at all stages ranging from reducing vasodilatation of the vessels in the affected area to avoid swelling and inflammatory cell recruitment in the affected area to induction of genes in the immune system cells to alter their response to inflammatory stimuli. [5]

The timing of glucocorticoid use can also influence the immune system in a completely opposite manner. Glucocorticoid administration about an hour after administration of endotoxin (Lipopolysccharides) was immunosuppressive but administration of the same glucocorticoid before the administration of endotoxin (lipopolysaccharide) augmented the immune response [5]. This poses an interesting challenge regarding the timing of glucocorticoid use in COVID -19 patients. Clinicians would need to strike the fine balance between suppressing immune system enough to avoid cytokine storm and leaving it potent enough to fight back 
the offending agents - nCOV-19 (novel corona virus 2019) in COVID-19 patients.

Dexamethasone has so far shown better survival results in critically ill patients requiring clinical care in ICU compared to patients requiring supplemental oxygen in the wards [6]. Does this mean Dexamethasone should not be used in patients not too unwell and its use can be detrimental in relatively asymptomatic patients? Are patients destined to get too unwell different from other patients right from the start of their disease and clinicians need to identify these patients to start steroid use earlier in these patients before they get to the stage of irreversible cytokine storm? Is nCOV-19 driving different pathological mechanisms in different patients? These are the questions to be answered and answered soon enough to reduce mortality. Dexamethasone seems to have made a start to answer some of these queries but we have still got more questions than answers.

\section{Are there any conflicts of interest?}

No

\section{References}

1. Bassetti M., Vena A., (2020) Roberto Giacobbe D. The Novel Chinese Coronavirus (2019-nCoV) Infections: challenges for fighting the storm. Eur. J. Clin. Invest. [PMC free article] [PubMed] [Google Scholar] [Ref list]

2. Cytokine storm of graft-versus-host disease: a critical effector role for interleukin-1.Ferrara JL, Abhyankar S, Gilliland DG Transplant Proc. 1993 Feb; 25(1 Pt 2):1216-7.[PubMed] [Ref list]

3. Tisoncik JR, Korth MJ, Simmons CP, Farrar J, Martin TR, Katze MG. (2012) Into the eye of the cytokine storm. Microbiol Mol Biol Rev. 76(1):16-32.

4. Velavan TP, Meyer CG. (2020) Mild versus severe COVID-19: Laboratory markers nt national Journal of Infectious diseases 95 304-307.

5. Coutinho AE, Chapman KE. (2011) The anti-inflammatory and immunosuppressive effects of glucocorticoids, recent developments and mechanistic insights. Mol Cell Endocrinol. 2011;335(1):2-13.

6. https://www.nature.com/articles/d41586-020-01824-5

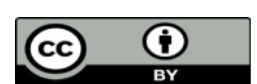

This work is licensed under Creative Commons Attribution 4.0 License

To Submit Your Article Click Here: Submit Article

DOI:10.31579/2692-9392/014
Ready to submit your research? Choose Auctores and benefit from:

* fast, convenient online submission

* rigorous peer review by experienced research in your field

* rapid publication on acceptance

* authors retain copyrights

* unique DOI for all articles

* immediate, unrestricted online access

At Auctores, research is always in progress.

Learn more www.auctoresonline.org/journals/archives-of-medical-casereports-and-case-study 